\title{
Drug-coated balloons in the treatment of acute myocardial infarction (Review)
}

\author{
HUILIN HU and LIANG SHEN
}

\begin{abstract}
Department of Cardiology, Affiliated Hospital of Jiaxing University, Jiaxing, Zhejiang 314000, P.R. China
\end{abstract}
Received July 29, 2020; Accepted February 8, 2021

DOI: $10.3892 /$ etm.2021.9895

\begin{abstract}
Drug-eluting stents are the standard revascularization strategy for the treatment of symptomatic coronary artery disease. However, in-stent restenosis (ISR), stent thrombosis and reinfarction of target lesions following stent implantation present challenges. Drug-coated balloons (DCBs), which deliver antiproliferative drugs into the vessel wall without stent implantation, are a novel treatment option for percutaneous coronary intervention and have been proven to act as a promising strategy in the treatment of ISR and coronary small vessel disease. However, their role in acute myocardial infarction (AMI) remains unclear. The present review discusses current evidence for the treatment of $\mathrm{AMI}$ with DCBs.
\end{abstract}

\section{Contents}

1. Introduction

2. DCBs

3. Clinical trials of DCBs for AMI

4. Limitations and perspectives

5. Conclusions

\section{Introduction}

Despite major advancements in primary and secondary prevention strategies, coronary artery disease (CAD) remains a major cause of morbidity and mortality worldwide (1-3). Percutaneous coronary intervention (PCI), which was introduced as an alternative means of coronary revascularization to coronary artery bypass grafting surgery in 1979 (4), is considered an effective and safe treatment modality for suitable patients with acute or stable CAD (1).

Correspondence to: Liang Shen, Department of Cardiology, Affiliated Hospital of Jiaxing University, 1882 Zhonghuan South Road, Jiaxing, Zhejiang 314000, P.R. China

E-mail: shenliang8011@126.com

Key words: drug-coated balloons, percutaneous coronary intervention, acute myocardial infarction
Patients with acute myocardial infarction (AMI) are among the highest-risk patients undergoing PCI. The introduction of stenting decreased the limitations of elastic recoil, restenosis and flow-limiting dissections associated with plain old balloon angioplasty (5). Due to their improved safety and efficacy compared with first-generation drug-eluting stents (DES) and bare-metal stents (BMS), new-generation DES are currently recommended for PCI in patients with AMI $(1,3)$. However, in-stent restenosis (ISR), increased risk of bleeding due to prolonged dual antiplatelet therapy, as well as early and late stent thrombosis following implantation (6-10). Furthermore, late stent-related major adverse cardiovascular events (MACEs) occur between 1-5 years after PCI, which presents a challenge (11). For patients with AMI, routine stenting is associated with an increased rate of acute and subacute stent thrombosis compared with stable CAD, and the 1-year incidence of target lesion-related events remains high $(12,13)$. In addition, permanent vascular implants impair coronary endothelial and vasomotor functions of the coronary artery (14).

These limitations resulted in the development of drug-coated balloons (DCBs). The rationale of DCB technology is that a combination of balloons and drugs is used for the treatment of coronary lesions to achieve lower rates of restenosis (Fig. 1) $(15,16)$. DCBs have emerged as a novel application in PCI, and a DCB strategy has already exhibited successful therapeutic potential for ISR (17-20) and small vessel disease (21-23). DCBs are a class I indication to treat ISR, as described in the 2018 ESC/EACTS guidelines on myocardial revascularization (1); however, their role in AMI remains unclear. The present review discusses the current studies for the treatment of AMI with DCBs.

\section{DCBs}

The concept of DCBs has been extensively studied $(15,24,25)$. DCBs are semi-compliant balloons covered with an antiproliferative drug, which is in direct contact with the vessel wall and inhibits the proliferation of smooth muscle cells (26). DCBs are a novel treatment strategy for CAD, based on the fast delivery of antiproliferative drugs into the vessel wall following single balloon inflation, which fulfills the concept of 'leaving nothing behind' $(27,28)$. Although sirolimus and its analogues have been investigated in DCBs, limited data are available for their use in CAD (29-31). Paclitaxel-coated balloons, which contain a typical dose of $2.0-3.5 \mathrm{mg} / \mathrm{mm}^{2}$ of paclitaxel on the balloon surface, remain a popular choice for coronary intervention (16). 


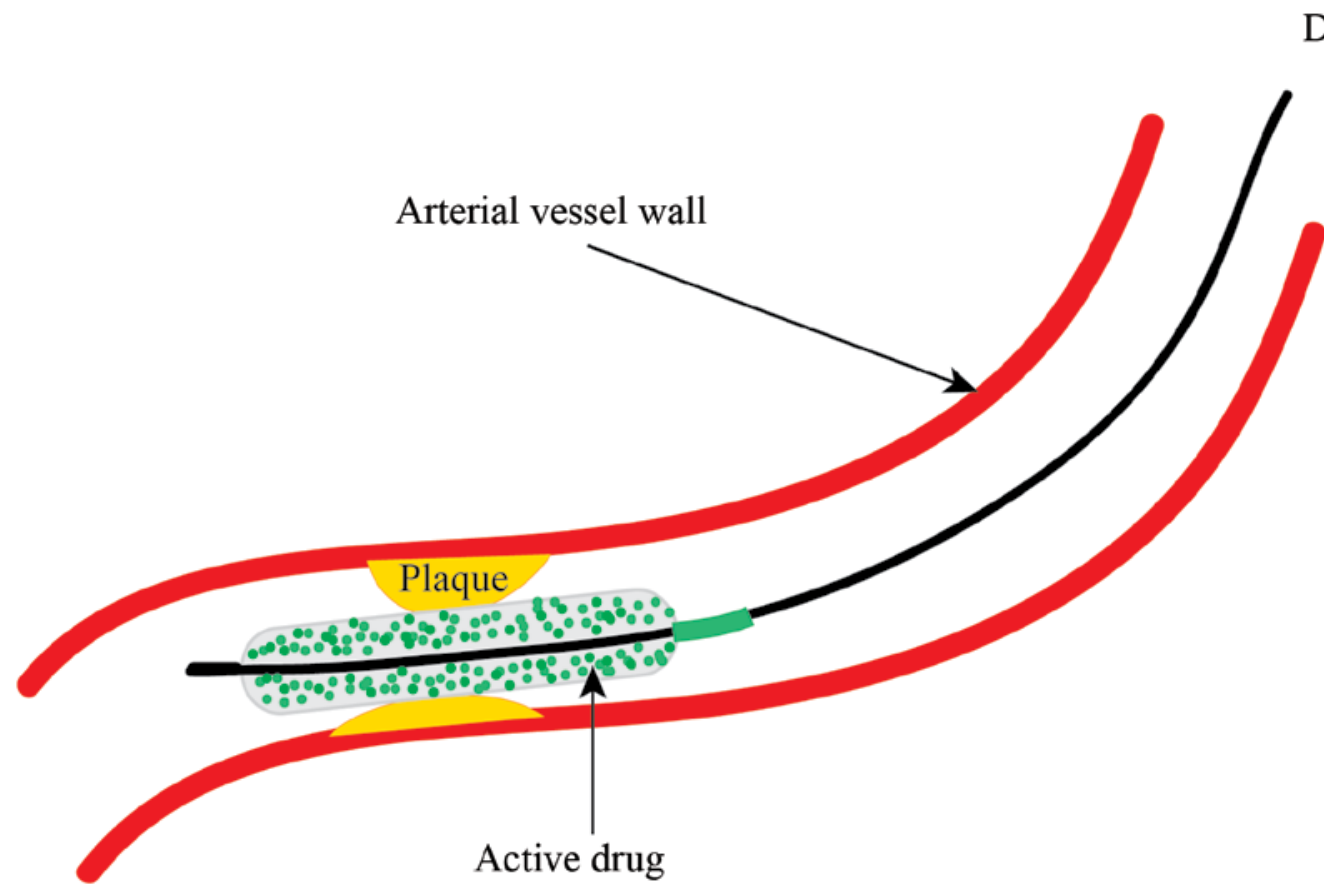

Figure 1. DCB Technique and Mechanism. DCB delivery of highly lipophilic drugs into the vessel wall by single balloon inflation. DCB, drug-coated balloon.

Paclitaxel is a highly lipophilic antiproliferative drug that can permeate through the vessel wall. In addition, it is relatively selective for smooth muscle cells, and its cytotoxicity persists for at least 14 days (26). Following inflation of the balloon for $30 \mathrm{sec}$, $16 \%$ of the drug is transferred into the vessel intima to exert a sufficient antiproliferative effect (32). Rapid tissue release makes paclitaxel-coated balloons attractive for use in DCBs. Table I lists currently available DCBs for coronary use, worldwide.

\section{Clinical trials of DCBs for AMI}

ST-segment elevation MI (STEMI). Primary percutaneous coronary intervention (PPCI) is the most effective reperfusion strategy for STEMI, and stenting has been demonstrated to decrease the incidence of repeat revascularization $(33,34)$. However, intervention stent treatment is associated with an increased rate of thrombotic complications, as well as ISR in the long-term $(10,13)$. Thus, avoiding permanent implants may be favorable to prevent stent-associated acute and long-term complications in patients with STEMI. A DCB strategy may be attractive because it provides a homogeneous delivery of the antiproliferative drug and also suppresses endothelial inflammation $(35,36)$.

Currently, five studies have been performed to investigate the DCB strategy in patients with STEMI (Table II). Ho et al (37) investigated the feasibility of using DCBs in patients undergoing PPCI by treating 89 patients with STEMI with 89 coronary lesions with DCBs, among which $56 \%$ of patients underwent thrombus aspiration and $4 \%$ of patients received bailout stenting. At 30 days follow-up, four deaths were reported; however, no patients experienced abrupt closure of the infarct-related artery, target vessel revascularization (TVR), target-vessel-MI or target lesion thrombosis. In this study, the authors recommended thrombus aspiration for visible thrombus and sufficient predilatation prior to DCB angioplasty to enable better contact, prolong balloon inflation and provide preliminary experiences with DCBs in PPCI. However, as the number of patients in the study was relatively small and it was a single-center registry, further studies with longer follow-up are required to confirm these preliminary findings.

The PAPPA study (38) prospectively enrolled 100 patients with STEMI and evaluated the safety and feasibility of a DCB-only strategy in PPCI. In this study, 59 patients were treated with a DCB angioplasty, while bailout stenting was performed in 41 patients due to type $\mathrm{C}$ to $\mathrm{F}$ dissection or residual stenosis $>50 \%$. 1-year clinical follow-up was completed in $98 \%$ of patients, and five MACEs were reported. A total of two patients died from cardiac death, and three patients underwent target lesion revascularization (TLR). To the best of our knowledge, this was the first study that exhibited good 1-year clinical results of a DCB-only strategy in the setting of primary PCI; however, its major limitations include its observational nature, single-arm and single-center design, and the lack of long-term follow-up.

Gobic et al (39) also compared the clinical and angiographic outcomes in patients with STEMI treated with DCB-only strategy vs. DES implantation during PPCI. A total of 75 patients with STEMI were randomized into DCB or DES groups, and the study endpoints were MACEs and late lumen loss (LLL) after 6-months follow-up. After 1 month, two patients in each group experienced reinfarction. At 6 months, MACEs were only reported in 5.4\% of patients in the DES group; LLL was $0.10 \pm 0.19 \mathrm{~mm}$ in the DES group and $-0.09 \pm 0.09 \mathrm{~mm}$ in the DCB group $(\mathrm{P}<0.05)$. This study demonstrated that the DCB-only strategy had good clinical and angiographic outcomes after a 6-months follow-up period. However, the limitations of this study included a small sample size, relatively short follow-up period and the lack of prior research on the topic. 
Table I. Currently approved drug-coated balloons.

\begin{tabular}{llll}
\hline Device & \multicolumn{1}{c}{ Company } & Drug & Dose, $\mu \mathrm{g} / \mathrm{mm}^{2}$ \\
\hline Agent & Boston Scientific & Paclitaxel & 2.0 \\
Elutax SV & Aachen Resonance & Paclitaxel & 2.2 \\
Danubio & Minvasys & Paclitaxel & 2.5 \\
Dior I and II & Eurocor & Paclitaxel & 3.0 \\
SeQuent Please Neo & Braun Melsungen & Paclitaxel & 3.0 \\
Pantera Lux & Biotronik & Paclitaxel & 3.0 \\
Restore & Cardionovum & Paclitaxel & 3.0 \\
Essential & iVascular & Paclitaxel & 3.0 \\
IN. PACT Falcon & Medtronic & Paclitaxel & 3.5 \\
Elutax & Aachen Resonance & Paclitaxel & 2.2 \\
Virtue & Caliber Therapeutics & Sirolimus & 4.0 \\
Selution & M.A. Med Alliance & Sirolimus & 4.0 \\
Magictouch & Concept Medical Research & Sirolimus & 4.0 \\
\hline
\end{tabular}

Table II. Clinical trials of DCBs for the treatment of ST-segment elevation myocardial infarction.

\begin{tabular}{|c|c|c|c|c|c|c|c|c|c|}
\hline Trial & Year & $\begin{array}{l}\text { DCB } \\
\text { type }\end{array}$ & $\begin{array}{l}\text { Control } \\
\text { group }\end{array}$ & $\begin{array}{c}\text { Sample } \\
\text { size, } n\end{array}$ & $\begin{array}{l}\text { Clinical } \\
\text { follow-up, } \\
\text { months }\end{array}$ & $\begin{array}{l}\text { Angiographic } \\
\text { follow-up, } \\
\text { months }\end{array}$ & $\begin{array}{l}\text { Primary } \\
\text { endpoint }\end{array}$ & $\begin{array}{l}\text { Secondary } \\
\text { endpoint }\end{array}$ & (Refs.) \\
\hline DEB-AMI & 2012 & DIOR II & $\begin{array}{l}\mathrm{DCB}+ \\
\text { BMS } \\
\text { or DES }\end{array}$ & $50 / 50 / 50$ & 6 & 6 & LLL & $\begin{array}{l}\text { ISR, MACE } \\
\text { (cardiac death, } \\
\text { MI and TVR) }\end{array}$ & (40) \\
\hline PAPPA & 2014 & $\begin{array}{l}\text { Pantera } \\
\text { Lux }\end{array}$ & None & 100 & 12 & None & $\begin{array}{l}\text { Cardiac death, } \\
\text { recurrent MI, } \\
\text { TLR }\end{array}$ & $\begin{array}{l}\text { The need for } \\
\text { additional } \\
\text { stenting, stent } \\
\text { thrombosis } \\
\text { and major } \\
\text { bleeding }\end{array}$ & (38) \\
\hline Ho et al & 2015 & $\begin{array}{l}\text { SeQuent } \\
\text { Please }\end{array}$ & None & 89 & 1 & None & $\begin{array}{l}\text { Death, TVR, } \\
\text { recurrent MI } \\
\text { or ST }\end{array}$ & NR & (37) \\
\hline Gobic et al & 2017 & $\begin{array}{l}\text { SeQuent } \\
\text { Please }\end{array}$ & DES & $41 / 37$ & 6 & 6 & $\begin{array}{l}\text { LLL, MACE } \\
\text { (major bleeding, } \\
\text { MI, TLR and } \\
\text { cardiac death) }\end{array}$ & NR & (39) \\
\hline REVELATION & 2019 & $\begin{array}{l}\text { Pantera } \\
\text { Lux }\end{array}$ & DES & $60 / 60$ & 9 & 9 & FFR value & $\begin{array}{l}\text { LLL, MACE } \\
\text { (cardiac death, } \\
\text { recurrent MI } \\
\text { and TLR) } \\
\text { and major } \\
\text { bleeding. }\end{array}$ & $(42)$ \\
\hline
\end{tabular}

DCB, drug-coated balloon; BMS, bare metal stent; DES, drug-eluting stent; LLL, late lumen loss; MACE, major adverse cardiovascular event; TLR, target lesion revascularization; MI, myocardial infarction; FFR, fractional flow reserve; TVR, target vessel revascularization; ISR, in-stent restenosis; NR, not reported.

The DEB-AMI trial (40), which compared intravascular imaging and clinical outcomes of patients with STEMI treated with BMS, DES or DCB plus BMS, demonstrated that the combination of DCB and BMS was not superior to BMS alone and inferior to paclitaxel-eluting stents, in terms of LLL and binary restenosis at 6-months follow-up. In the non-randomized fourth arm of the DEB-AMI study, Nijhoff et al (41) reported that DCB-only treatment resulted in a similar LLL 


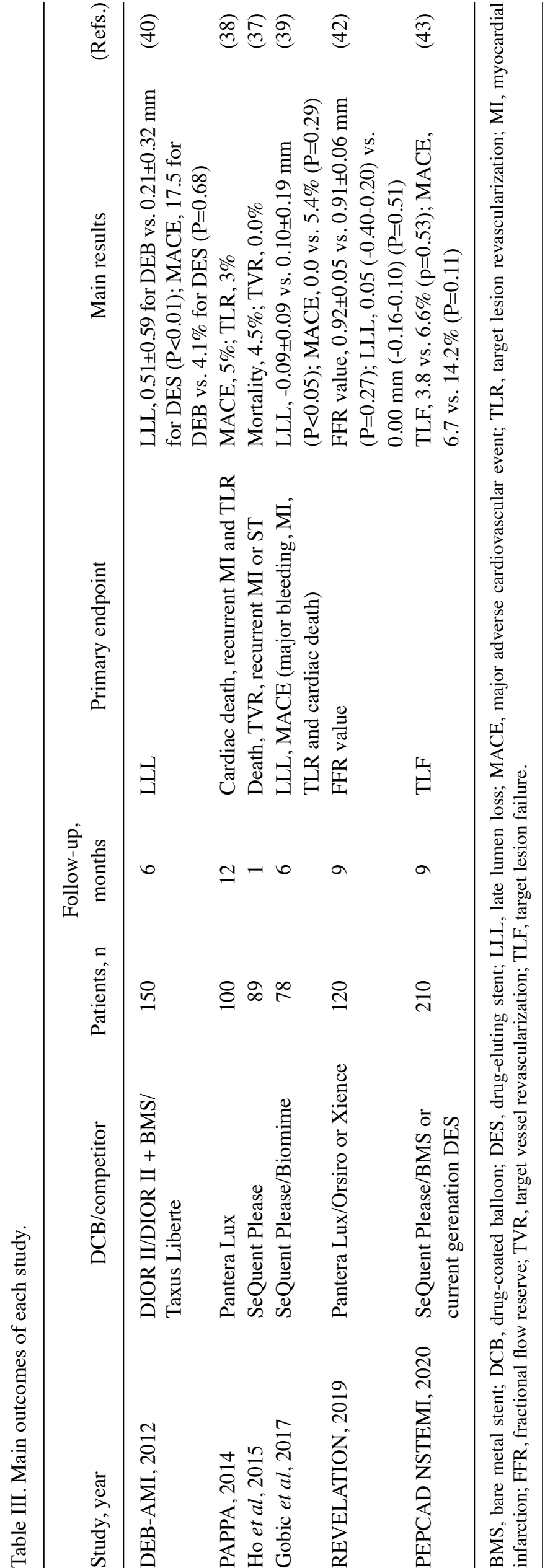

and binary restenosis rate compared with treatment with BMS alone or DCB plus BMS; however, significantly higher LLL and binary restenosis rate were achieved compared with the DES group, which may be due to the DCB compound used in the study (DIOR GmbH, Bonn, Germany). Notably, no statistically significant differences in MACEs, death, TLR, TVR, myocardial infarction and stent thrombosis rates were observed between DEB-only and DES treatments at 6-months follow-up. Thus, DEB-only treatment remains a potential alternative during PPCI in patients with contraindications to DES.

Recently, the REVELATION trial (42) was published, which was performed in patients with STEMI to assess the efficacy and safety of a DCB treatment strategy vs. DES treatment in PPCI. In this prospective randomized trial, 120 patients were treated with either DCB (Pantera Lux, Biotronik, Berlin, Germany) or DES (Orsiro, Biotronik, Bülach, Switzerland or Xience, Abbott) in a 1:1 ratio, and the primary endpoint was fractional flow reverse (FFR) at 9 months. At 9-months follow-up, the mean FFR value was $0.92 \pm 0.05$ in the DCB group vs. $0.91 \pm 0.06$ in the DES group $(\mathrm{P}=0.27)$. Furthermore, no significant differences in LLL and clinical outcomes were observed between the DCB and DES groups. The DCB-only strategy was non-inferior to DES treatment, and exhibited improved safety and feasibility. However, this study had several limitations, including a small sample size, relatively short follow-up period and it was a single-center study.

Non-ST elevation MI (NSTEMI). Only one study (PEPCAD NSTEMI) has compared the clinical outcomes of patients with NSTEMI treated with DCBs or stent (43). In this study, 210 patients with NSTEMI were enrolled, the primary endpoint was target lesion failure (TLF), and second endpoints included MACEs and individual clinical endpoints. During a follow-up of $9.2 \pm 0.7$ months, DCB was determined to be superior to stents in terms of TLF, and no significant difference in the rates of death, MI and TLR was observed between DCB and stent treatments. DES are regarded as the standard of care in most settings of acute coronary syndrome $(3,33)$, and the PEPCAD NSTEMI trial was the first to demonstrate the safety and efficacy of DCBs for patients with NSTEMI. However, DCBs in this setting require further investigation in the form of larger randomized trials.

\section{Limitations and perspectives}

DCBs appear to be a feasible and attractive treatment strategy for patients with AMI. However, DCB technology is not without limitations. DCBs are associated with increased risk of persistent residual stenosis and acute dissection, which may require bailout stenting $(44,45)$. Furthermore, DCBs require optimal lesion preparation before the apposition of the drug-coating surface to the lesion endothelium, and in the presence of angiographic thrombus, DCBs may be unsuitable due to inhibition of drug delivery to the vessel wall $(37,42,46)$. In addition, in patients who had DES-ISR, DCBs may be associated with higher TLR compared with DES (18).

Limited data are available for the use of DCBs in AMI (Table III) and current studies have several limitations. First, 
the number of patients included in the studies have been relatively small. Secondly, the follow-up periods have been relatively short, whereby the longest follow-up period was only 12 months. Thus, the long-term safety and efficacy of DCBs in AMI remain unknown. Thirdly, despite half of the studies being randomized controlled trials (RCTs), only one study is a multi-center study. Finally, only paclitaxel-coated balloons were used in these studies, and no trails have investigated the safety and efficacy of other DCBs in AMI, such as sirolimus-coated.

Regarding the shortcomings of existing studies, larger multi-center RCTs with longer follow-up periods are required to evaluate the clinical use of paclitaxel or sirolimus-coated balloons in patients with AMI. Currently, sirolimus and its derivatives, such as everolimus, are successfully implemented in stent technology and are the main drugs used in DES in clinical practice (47-49). A recent study reported promising results of sirolimus-coated balloons ISR compared with paclitaxel-coated balloons (30). According to its success in stents and recent evidence in DCBs, sirolimus and its derivatives may be alternative drug coatings for AMI.

\section{Conclusions}

Stenting remains the standard reperfusion strategy in most settings of AMI; however, ISR, stent thrombosis and reinfarction present challenges. DCBs represent a safe and effective method for the treatment of ISR and coronary small vessel disease, and appear to be a promising strategy in the cases of AMI. However, further studies are required to determine the long-term benefits of DCBs compared with those of new-generation DES.

\section{Acknowledgements}

Thanks to the Jiaxing Institute of Arteriosclerotic Diseases.

\section{Funding}

The present review was supported by the Key Medicine Disciplines Co-construction Project of Jiaxing Municipal (grant no. 2019-ss-xxgbx).

\section{Availability of data and materials}

Not applicable.

\section{Authors' contributions}

HH drafted the initial manuscript and LS performed the literature review. HH and LS confirm the authenticity of all the raw data. All authors read and approved the final manuscript.

\section{Ethics approval and consent to participate}

Not applicable.

\section{Patients consent for publication}

Not applicable.

\section{Competing interests}

The authors declare that they have no competing interests.

\section{References}

1. Neumann FJ, Sousa-Uva M, Ahlsson A, Alfonso F, Banning AP, Benedetto U, Byrne RA, Collet JP, Falk V, Head SJ, et al: 2018 ESC/EACTS guidelines on myocardial revascularization. Eur Heart J 40: 87-165, 2019.

2. Knuuti J, Wijns W, Saraste A, Capodanno D, Barbato E, Funck-Brentano C, Prescott E, Storey RF, Deaton C, Cuisset T, et al: 2019 ESC guidelines for the diagnosis and management of chronic coronary syndromes. Eur Heart $\mathbf{J} 41$ : 407-477, 2020.

3. Collet JP, Thiele H, Barbato E, Barthelemy O, Bauersachs J, Bhatt DL, Dendale P, Dorobantu M, Edvardsen T, Folliguet T, et al: 2020 ESC guidelines for the management of acute coronary syndromes in patients presenting without persistent ST-segment elevation. Eur Heart J ehaa 575, 2020.

4. Gruntzig AR, Senning A and Siegenthaler WE: Nonoperative dilatation of coronary-artery stenosis: Percutaneous transluminal coronary angioplasty. N Engl J Med 301: 61-68, 1979.

5. McKavanagh P, Zawadowski G, Ahmed N and Kutryk M: The evolution of coronary stents. Expert Rev Cardiovasc Ther 16: 219-228, 2018

6. Huang KN, Grandi SM, Filion KB and Eisenberg MJ: Late and very late stent thrombosis in patients with second-generation drug-eluting stents. Can J Cardiol 29: 1488-1494, 2013.

7. Chang $M$ and Park DW: Optimal duration of dual antiplatelet therapy after implantation of drug-eluting stents: Shorter or longer? Cardiol Ther 3: 1-12, 2014.

8. Hassan AK, Bergheanu SC, Stijnen T, van der Hoeven BL, Snoep JD, Plevier JW, Schalij MJ and Wouter Jukema J: Late stent malapposition risk is higher after drug-eluting stent compared with bare-metal stent implantation and associates with late stent thrombosis. Eur Heart J 31: 1172-1180, 2010.

9. Cassese S, Byrne RA, Tada T, Pinieck S, Joner M, Ibrahim T, King LA, Fusaro M, Laugwitz KL and Kastrati A: Incidence and predictors of restenosis after coronary stenting in 10004 patients with surveillance angiography. Heart 100: 153-159, 2014.

10. Byrne RA, Joner M and Kastrati A: Stent thrombosis and restenosis: What have we learned and where are we going? The andreas gruntzig lecture ESC 2014. Eur Heart J 36: 3320-3331, 2015.

11. Madhavan MV, Kirtane AJ, Redfors B, Genereux $P$, Ben-Yehuda O, Palmerini T, Benedetto U, Biondi-Zoccai G, Smits PC, von Birgelen C, et al: Stent-related adverse events $>1$ year after percutaneous coronary intervention. J Am Coll Cardiol 75: 590-604, 2020.

12. Loh JP, Pendyala LK, Kitabata H, Torguson R, Omar A, Minha S, Chen F, Satler LF, Pichard AD and Waksman R: Comparison of outcomes after percutaneous coronary intervention among different coronary subsets (stable and unstable angina pectoris and ST-segment and non-ST-segment myocardial infarction). Am J Cardiol 113: 1794-1801, 2014.

13. Gonzalo N, Barlis P, Serruys PW, Garcia-Garcia HM, Onuma Y, Ligthart J and Regar E: Incomplete stent apposition and delayed tissue coverage are more frequent in drug-eluting stents implanted during primary percutaneous coronary intervention for ST-segment elevation myocardial infarction than in drug-eluting stents implanted for stable/unstable angina: Insights from optical coherence tomography. JACC Cardiovasc Interv 2: 445-452, 2009.

14. Hung MJ, Hsu KH, Chang NC, Tsimikas S and Hung MY: Prevalence of coronary artery spasm after stent placement and its association with inflammation. Int J Cardiol 179: 252-255, 2015.

15. Ang H, Lin J, Huang YY, Chong TT, Cassese S, Joner M and Foin N: Drug-Coated balloons: Technologies and clinical applications. Curr Pharm Des 24: 381-396, 2018.

16. Jeger RV, Eccleshall S, Wan Ahmad WA, Ge J, Poerner TC, Shin ES, Alfonso F, Latib A, Ong PJ, Rissanen TT, et al: Drug-coated balloons for coronary artery disease: Third report of the international DCB consensus group. JACC Cardiovasc Interv 13: 1391-1402, 2020.

17. Scheller B, Hehrlein C, Bocksch W, Rutsch W, Haghi D, Dietz U, Bohm M and Speck U: Treatment of coronary in-stent restenosis with a paclitaxel-coated balloon catheter. N Engl J Med 355: 2113-2124, 2006 
18. Giacoppo D, Alfonso F, Xu B, Claessen BEPM, Adriaenssens T, Jensen C, Perez-Vizcayno MJ, Kang DY, Degenhardt R, Pleva L, et al: Paclitaxel-coated balloon angioplasty vs. drug-eluting stenting for the treatment of coronary in-stent restenosis: A comprehensive collaborative, individual patient data meta-analysis of 10 randomized clinical trials (DAEDALUS study). Eur Heart J 41: 3715-3728, 2020.

19. Rittger H, Brachmann J, Sinha AM, Waliszewski M, Ohlow M, Brugger A, Thiele H, Birkemeyer R, Kurowski V, Breithardt OA, et al: A randomized, multicenter, single-blinded trial comparing paclitaxel-coated balloon angioplasty with plain balloon angioplasty in drug-eluting stent restenosis: The PEPCAD-DES study. J Am Coll Cardiol 59: 1377-1382, 2012.

20. Scheller B, Clever YP, Kelsch B, Hehrlein C, Bocksch W, Rutsch W, Haghi D, Dietz U, Speck U, Böhm M and Cremers B Long-term follow-up after treatment of coronary in-stent restenosis with a paclitaxel-coated balloon catheter. JACC Cardiovasc Interv 5: 323-330, 2012.

21. Jeger RV, Farah A, Ohlow MA, Mangner N, Mobius-Winkler S, Leibundgut G, Weilenmann D, Wohrle J, Richter S, Schreiber M, et al: Drug-coated balloons for small coronary artery disease (BASKET-SMALL 2): An open-label randomised non-inferiority trial. Lancet 392: 849-856, 2018.

22. Cortese B, Micheli A, Picchi A, Coppolaro A, Bandinelli L, Severi S and Limbruno U: Paclitaxel-coated balloon versus drug-eluting stent during PCI of small coronary vessels, a prospective randomised clinical trial. The PICCOLETO study. Heart 96: 1291-1296, 2010.

23. Latib A, Colombo A, Castriota F, Micari A, Cremonesi A, De Felice F, Marchese A, Tespili M, Presbitero P, Sgueglia GA et al: A randomized multicenter study comparing a paclitaxel drug-eluting balloon with a paclitaxel-eluting stent in small coronary vessels: The BELLO (Balloon elution and late loss optimization) study. J Am Coll Cardiol 60: 2473-2480, 2012.

24. Waksman R and Pakala R: Drug-eluting balloon: The comeback kid? Circ Cardiovasc Interv 2: 352-358, 2009.

25. Wessely R: New drug-eluting stent concepts. Nat Rev Cardiol 7: 194-203, 2010.

26. Axel DI, Kunert W, Goggelmann C, Oberhoff M, Herdeg C, Kuttner A, Wild DH, Brehm BR, Riessen R, Köveker G and Karsch KR: Paclitaxel inhibits arterial smooth muscle cell proliferation and migration in vitro and in vivo using local drug delivery. Circulation 96: 636-645, 1997.

27. Yerasi C, Case BC, Forrestal BJ, Torguson R, Weintraub WS Garcia-Garcia HM and Waksman R: Drug-coated balloon for de novo coronary artery disease: JACC state-of-the-art review. J Am Coll Cardiol 75: 1061-1073, 2020.

28. Cheng Y, Leon MB and Granada JF: An update on the clinical use of drug-coated balloons in percutaneous coronary interventions. Expert Opin Drug Deliv 13: 859-872, 2016.

29. Verheye S, Vrolix M, Kumsars I, Erglis A, Sondore D, Agostoni P, Cornelis K, Janssens L, Maeng M, Slagboom T, et al: The SABRE trial (Sirolimus angioplasty balloon for coronary in-stent restenosis): Angiographic results and 1-year clinical outcomes. JACC Cardiovasc Interv 10: 2029-2037, 2017.

30. Ali RM, Abdul Kader MASK, Wan Ahmad WA, Ong TK, Liew HB, Omar AF, Mahmood Zuhdi AS, Nuruddin AA, Schnorr B and Scheller B: Treatment of coronary drug-eluting stent restenosis by a sirolimus- or paclitaxel-coated balloon. JACC Cardiovasc Interv 12: 558-566, 2019.

31. Cortese B, Di Palma G and Latini R: Magic Touch ${ }^{(\mathrm{R})}$ : Preliminary clinical evidence with a novel sirolimus drug coated balloon. Minerva Cardioangiol 66: 508-517, 2018.

32. Scheller B, Speck U, Abramjuk C, Bernhardt U, Bohm M and Nickenig G: Paclitaxel balloon coating, a novel method for prevention and therapy of restenosis. Circulation 110: 810-814, 2004

33. Ibanez B, James S, Agewall S, Antunes MJ, Bucciarelli-Ducci C, Bueno H, Caforio ALP, Crea F, Goudevenos JA, Halvorsen S, et al 2017 ESC Guidelines for the management of acute myocardial infarction in patients presenting with ST-segment elevation: The Task Force for the management of acute myocardial infarction in patients presenting with ST-segment elevation of the European society of cardiology (ESC). Eur Heart J 39: 119-177, 2018.

34. Alawami M, Sadler M, Kasargod C, Watson T, Webster M and Ruygrok P: Outcomes of patients with ST elevation myocardial infarction in the era of second-generation drug eluting stents; five-year follow-up. N Z Med J 132: 34-41, 2019.

35. Herdeg C, Oberhoff M, Baumbach A, Blattner A, Axel DI, Schroder S, Heinle H and Karsch KR: Local paclitaxel delivery for the prevention of restenosis: Biological effects and efficacy in vivo. J Am Coll Cardiol 35: 1969-1976, 2000.
36. Oberhoff M, Kunert W, Herdeg C, Kuttner A, Kranzhofer A, Horch B, Baumbach A and Karsch KR: Inhibition of smooth muscle cell proliferation after local drug delivery of the antimitotic drug paclitaxel using a porous balloon catheter. Basic Res Cardiol 96: 275-282, 2001.

37. Ho HH, Tan J, Ooi YW, Loh KK, Aung TH, Yin NT, Sinaga DA, Jafary FH and Ong PJ: Preliminary experience with drug-coated balloon angioplasty in primary percutaneous coronary intervention. World J Cardiol 7: 311-314, 2015.

38. Vos NS, Dirksen MT, Vink MA, van Nooijen FC, Amoroso G, Herrman JP, Kiemeneij F, Patterson MS, Slagboom T and van der Schaaf RJ: Safety and feasibility of a PAclitaxel-eluting balloon angioplasty in Primary Percutaneous coronary intervention in Amsterdam (PAPPA): One-year clinical outcome of a pilot study. EuroIntervention 10: 584-590, 2014.

39. Gobic D, Tomulic V, Lulic D, Zidan D, Brusich S, Jakljevic T and Zaputovic L: Drug-coated balloon versus drug-eluting stent in primary percutaneous coronary intervention: A feasibility study. Am J Med Sci 354: 553-560, 2017.

40. Belkacemi A, Agostoni P, Nathoe HM, Voskuil M, Shao C, Van Belle E, Wildbergh T, Politi L, Doevendans PA, Sangiorgi GM and Stella PR: First results of the DEB-AMI (drug eluting balloon in acute ST-segment elevation myocardial infarction) trial: A multicenter randomized comparison of drug-eluting balloon plus bare-metal stent versus bare-metal stent versus drug-eluting stent in primary percutaneous coronary intervention with 6-month angiographic, intravascular, functional, and clinical outcomes. J Am Coll Cardiol 59: 2327-2337, 2012.

41. Nijhoff F, Agostoni P, Belkacemi A, Nathoe HM, Voskuil M, Samim M, Doevendans PA and Stella PR: Primary percutaneous coronary intervention by drug-eluting balloon angioplasty: The nonrandomized fourth arm of the DEB-AMI (drug-eluting balloon in ST-segment elevation myocardial infarction) trial. Catheter Cardiovasc Interv 86 (Suppl 1): S34-S44, 2015.

42. Vos NS, Fagel ND, Amoroso G, Herrman JR, Patterson MS, Piers LH, van der Schaaf RJ, Slagboom T and Vink MA: Paclitaxel-coated balloon angioplasty versus drug-eluting stent in acute myocardial infarction: The REVELATION randomized trial. JACC Cardiovasc Interv 12: 1691-1699, 2019.

43. Scheller B, Ohlow MA, Ewen S, Kische S, Rudolph TK, Clever YP, Wagner A, Richter S, El-Garhy M, Böhm M, et al: Bare metal or drug-eluting stent versus drug-coated balloon in non-ST-elevation myocardial infarction: The randomised PEPCAD NSTEMI trial. EuroIntervention 15: 1527-1533, 2020.

44. Liu Y, Zhang YJ, Deng LX, Yin ZY, Hu T, Wang Q, Li Y, Li JY, Guo WY, Mou FJ and Tao L: 12-Month clinical results of drug-coated balloons for de novo coronary lesion in vessels exceeding $3.0 \mathrm{~mm}$. Int J Cardiovasc Imaging 35: 579-586, 2019.

45. Venetsanos D, Lawesson SS, Panayi G, Todt T, Berglund U, Swahn E and Alfredsson J: Long-term efficacy of drug coated balloons compared with new generation drug-eluting stents for the treatment of de novo coronary artery lesions. Catheter Cardiovasc Interv 92: E317-E326, 2018.

46. Megaly M,Buda KG, Xenogiannis I, Vemmou E, Nikolakopoulos I, Saad M, Rinfret S, Abbott JD, Aronow HD, Garcia S, et al: Systematic review and meta-analysis of short-term outcomes with drug-coated balloons vs. stenting in acute myocardial infarction. Cardiovasc Interv Ther: Oct 10, 2020 (Epub ahead of print).

47. Claessen BE, Henriques JP and Dangas GD: Clinical studies with sirolimus, zotarolimus, everolimus, and biolimus A9 drug-eluting stent systems. Curr Pharm Des 16: 4012-4024, 2010.

48. Navarese EP, Tandjung K, Claessen B, Andreotti F, Kowalewski M, Kandzari DE, Kereiakes DJ, Waksman R, Mauri L, Meredith IT, et al: Safety and efficacy outcomes of first and second generation durable polymer drug eluting stents and biodegradable polymer biolimus eluting stents in clinical practice: Comprehensive network meta-analysis. BMJ 347: f6530, 2013

49. Sabate M, Raber L, Heg D, Brugaletta S, Kelbaek H, Cequier A, Ostojic M, Iniguez A, Tuller D, Serra A, et al: Comparison of newer-generation drug-eluting with bare-metal stents in patients with acute ST-segment elevation myocardial infarction: A pooled analysis of the EXAMINATION (clinical Evaluation of the Xience-V stent in Acute Myocardial INfArcTION) and COMFORTABLE-AMI (Comparison of Biolimus Eluted From an Erodible Stent Coating With Bare Metal Stents in Acute ST-Elevation Myocardial Infarction) trials. JACC Cardiovasc Interv 7: 55-63, 2014.

This work is licensed under a Creative Commons Attribution-NonCommercial-NoDerivatives 4.0 International (CC BY-NC-ND 4.0) License. 